The deep sadness and inevitable changes of the body and mind revoking and facing the upcoming end of the artist's career and life itself. Late style narration represented foremost in plain fear of death, recreation of past as the interfering part of the present that objecting future as possibility for oneself but for forthcoming generations. The charm of California and her style, the women, Didion's family coexists with the fog, fire and rain - a real beauty in the middle of the disaster. It has become a starting point of re- and deflection of autobiographic motives and fictionalized glimpses of history.

\title{
References:
}

1. Said, E. (2006). On Late Style: Music and Literature Against the Grain. Bloomsbury Publishing Plc.

2. Zehelein, E.-S. (2011). A good deal about California does not, on its own preferred terms, add up»: Joan Didion between Dawning Apocalypse and Retrogressive Utopia. European journal of American studies, document 6, 1-13. doi: https://doi.org/10.4000/ejas.9324

3. Didion, J. (2011). Blue Nights. Vintage, 208 p.

\section{THE INTERPRETATION OF THE IMAGE OF OLGA IN OF THE «OLD OF KIEV LEGENDS» NATALENA KOROLEVAS}

\section{Yulia Kovalchuk ${ }^{1}$}

DOI: https://doi.org/10.30525/978-9934-588-39-6-19

A literary work only then fulfills its functional purpose when it enters into the consciousness, imagination and emotional sphere of the Other. Then there is its «assignment», which is preceded by a peculiar process consisting of perception, understanding and interpretation. Known scheme «author - work reader» can be implemented in completed form, provided the practical understanding and interpretation of the content of the work, transmitted in some artistic form. Being a literary phenomenon is determined not only by the aspirations and creative activity of the author, fixation on writing in the form of text, but mainly by the intertextual and spiritual work of the researcher or reader, who reproduces, enlivens and interprets the images and meanings of the once created artistic world. Ever since there is an artistic word, since then its interpretation has been carried out [2, p. 5].

\footnotetext{
${ }^{1}$ Zhytomyr State University named after Ivan Franko, Ukraine
} 
One of the means of artistic interpretation is intertextuality, or intertextuality, that is, the presence in one text of other texts interpreted for its «divinity» (O. Mishanich). This is the reason for the existence of the literary work of Modernity and the creation of «author model» (N. Astrakhan) or his own «microcosm» (O. Mishanich).

The interpretation of a literary work exists in the context of a scientific concept - hermeneutics. In terms of etymology, this word has three meanings: to express, to interpret, to translate. Initially, it concerned the oral expression of the oracle, later the object of hermeneutics became sacred ancient texts, and later - chronicles and other sources, drawing on wisdom, moral and spiritual potential and statements of historical events and personalities.

Later on, those between text links became known as «intertext».

Particularly active in the Ukrainian territory is developing historical and literary direction. Rereading works of art through the lens of intertextual theory reveals research perspectives related to the creation of new models of interpretation, a deepened awareness of the patterns of global intercultural communication, to which various national and regional literatures are involved [7, p. 6].

A striking representative of the synthesis of several cultures, a large number of texts and worldviews in her own work is Natalena Koroleva. This extraordinary personality came to the territory of Ukrainian literature in the 90-s of the XX century. Therefore, research into her work is currently very relevant. Such literary critics as I. Golubovskaya, I. Nabitovych, Y. Kovalov, O. Myshanich and others have addressed the study of her literary heritage.

Natalena Koroleva is an outstanding phenomenon in the history of Ukrainian literature. She introduced new themes from the ancient and European world into Ukrainian prose, successfully continuing the traditions of Lesya Ukrainka.

Working on historical and biblical themes, the writer deliberately circumvented at least some invisible faces to connect the world of ancient Scythia, Russia and Ukraine with the world of antiquity and the Middle Ages. She updated some genres of prose in Ukrainian literature: brought to the classical virtuosity the genre of historical tale, unleashed the genre of literary legend, successfully combining the pagan, ancient, Scythian and Old Russian worlds with biblical, Christian.

Natalena Koroleva found in Ukrainian literature her individual artistic world characterized by a symbiosis of Romanesque, Arabic, Greco-Roman, Byzantine and Slavic styles [4, p. 84].

A striking example of such intertextual connections and worldviews of pagan and Christian is the Stories of the «Old of Kiev Legends». 
The cycle «Old of Kiev Legends» was completed in the 40s. These are 25 legendary stories, each of which can be the subject of a separate conversation, containing a complete set of thoughts, ideas, beliefs, worlds and facts [4, p 108]. The collection is thematically divided into three cycles: the story of Scythian, Kievan Rus and Kiev-Pechersk paterik. The key figure both in the history of Kievan Rus and in the collection of «Old of Kiev Legends» is Olga and her adoption of Christianity, the affirmation of women's power, prudence and power. After all, there were not many women in the history of mankind who could bring hundreds of thousands of men behind them and keep entire powerful states at their disposal.

Under the pen of Nestor, the multifaceted personality of Olga, the wife of Prince Igor, becomes legendary. The knitting of facts makes it difficult to recreate historical reality.

Chronologe sources do not report either the time of the princess's birth or her origin, but only state that in 903 they «brought a wife from Pskov to Igor named after Olga» [3, p. 19].

Olga gets to the pages of history in The Story of the Past Years at a very old age, after the death of her husband Igor. And she immediately established herself as a wise, cunning and circumspect personality: «Olga was in Kiev with her son, baby Svyatoslav, and the governor was Sveneld. Drevlyans said: We have killed the prince of Russia. Let's take his wife Olga and give her for our prince Mala... Olga told them: - I love your thing. I will not resurrect my husband already, and I want to honor you tomorrow before your people» (and Olga's first revenge occurred) [6, p. 33-34].

Wisely, judiciously and cunningly, we meet Olga on the pages of the collection of stories «Old of Kiev Legends» by Natalena Koroleva.

Of the 25 legends, this historical figure is not one of us. Princess of Kievan Rus, wise lord, faithful wife, vengeful woman, the first baptized in Russia, a woman with a male male character of combat warfare: "And Anastasia noted that the Russian nostalgia called her princess Elga - Olga. This name appeared to Anastasia so sweet and graceful girlish that suddenly worried thoughts flashed sparkle-hermit: Such a beauty Olga would not dare to grasp in his arms, nor the basileus himself, as he had just tried to detain her, Anastasia, Justinian... Because it seemed: only when Elga slides her wide eyebrows, then the thunder will sound like the times of ancient Zeus. And when she looks indignant, then her steel, gray, like a hunting falcon's eyes glitter. And long, dark, not gray hair, and pearls strewn with braids will strain their bones and become the princess's defense» («The Way of Salvation») [5, p. 83].

Indeed - the slightest surprise in her steel eyes. All her machinations of the «Solomon throne» for her are only a final stroke of the ritual, and therefore she bows her head with dignity a little...» [5, p. 86]. 
The interpretation of the image of Princess Olga in the collection of «Old of Kiev Legends» is a leading motive of her visit to Byzantium and baptism (named after Helen): «Princess Olga threw a heavy gold chain from her neck with an empty coffin medallion flavored with the most precious gift of basil: the part of the Holy Cross that could receive baptism... Christ's faith will be brought to Tavrida and to Russia-Ukraine by Helen. For the name of reception in holy baptism» («Shinkarivna») [5, p. 192].

The very "walking» of Olga to Constantinople is clearly described by Nestor in the Story of the Past Years. Although some moments with an event date have options.

Natalena Koroleva knows and feels medieval spirituality, skillfully and convincingly pursues a medieval "philosophy of history» according to which everything on earth is ordered by a single law: two principles are fighting in man - good and evil, and man is given the good will to choose between them [4, p. 96].

Natalena Koroleva did not focus on versions of Olga's Christianity. The author drew attention to careful justification, prudence of the princess before a serious step for the whole state, and making the right decision.

\section{References:}

1. Astrakhan N. Buttia literaturnoho tvoru: analitychne ta interpretatsiine modeliuvannia: monohrafiia / Nataliia Astrakhan. Kyiv: Akademvydav, 2014. $432 \mathrm{~s}$.

2. Bilous P. V. Interpretatsiia literaturnoho tvoru / P.V. Bilous. Zhytomyr: ZhDU, 2012. $140 \mathrm{~s}$.

3. Vydatni postati $\mathrm{v}$ istorii Ukrainy (IX - XIX st.): korotki biohrafichni narysy. Istorychni ta khudozhni portrety: Dovid. vyd. / V. I. Husiev, V. P. Drozhzhyn, Yu. O. Kolittsev, O. H. Sokyrko, V. I. Chervinskyi. Kyiv: Vyshcha shkola, 2002. 359 s.

4. Myshanych O. Povernennia. 2-e vyd., pererob. i dop. Kyiv: AT «Oberehy», 1997. $336 \mathrm{~s}$.

5. Natalena Koroleva. Lehendy starokyivski / Red. N. V. Soiko. Kyiv: Shkola, 2006. $256 \mathrm{~s}$.

6. Povist vremianykh lit / Khud.-oformliuvach A. S. Lenchyk. Kharkiv: Folio, 2005. $317 \mathrm{~s}$.

7. Skoryna L. «Homin ta vidhomin»: dyskurs intertekstualnosti v ukrainskii literaturi 1920-kh rokiv: Monohrafiia. Cherkasy: Brama-Ukraina, 2019. 704 s. 